\title{
THE EFFECTS OF REGIONAL LAND USE CONTROL IN OREGON: A THEORETICAL AND EMPIRICAL REVIEW
}

\author{
Gerrit J. Knaap and Arthur C. Nelson*
}

\section{Introduction}

Following the passage of the Standard State Zoning Enabling Act in 1922, most states passed legislation that delegated virtually all land use control to local govemments. Directed to promote the general welfare, local governments subsequently enacted a variety of zoning ordinances. But critics of zoning charged that local governments did not promote the general welfare but instead used zoning to promote parochial social and fiscal interests (Babcock, 1966). As a result, land use control in several states, including Florida, Hawaii, Oregon, and Vermont, became regionalized or recaptured in part by state governments during what some describe as the "Quiet Revolution" in land use control (Bosselman and Callies, 1971). Today, a substantial literature has developed describing and comparing the political, legal, and administrative components of the various statewide land use programs (Rosenbaum, 1976; Healy and Rosenberg, 1979; Pelham, 1979; DeGrove, 1984). Yet, no attempts to address systematically the impact of state participation in land use control or land allocation have been published. This paper seeks to fill that void.

This paper examines the impact of state government in the Oregon land use program. For several reasons the State of Oregon offers an ideal setting for examining the impact of state participation in land use regulation. First, Oregon is a pioneer in statewide land use regulation. The Oregon land use statutes were enacted in 1973, long enough ago to have had measurable impacts. Second, the Oregon land use program requires both state and local participation in land use regulation. In 1974 the Oregon State Land Conservation and Development Commission (LCDC), a governor-appointed commission, adopted 19 statewide land use goals and guidelines. Subsequently, every local government had to construct comprehensive land use plans in conformance with these goals and guidelines or suffer stiff non-compliance penalties and/or state preemption of land use authority. Compliance with the goals and guidelines is determined through an acknowledgement process by the Department of Land Conservation and Development (DLCD), the administrative *Respectively, assistant professor of urban and public affairs, University of Wisconsin-Green Bay; and associate professor of city planning, Georgia Institute of Technology. arm of the LCDC. All of the comprehensive plans of the 246 local governments have now been acknowledged by the DLCD. As a result, the Oregon land use program contains a mix of state and local land use controls. Third, the Oregon land use program has been the subject of considerable theoretical and empirical research. This research offers insights into the impacts of state participation in land use regulation.

\section{Urban Growth Boundaries}

Urban growth boundaries (UGBs), the cornerstone of the Oregon land use program, encompass every urban area in the state (DeGrove, 1984; Leonard, 1983). The concept of the urban growth boundary developed out of the efforts of Marion and Polk counties and the city of Salem to coordinate the management of Salem metropolitan growth. This led to the creation of the first urban development stopline anywhere in the U.S. (Nelson, 1985). From the beginning, the UGB concept was an intergovernmental approach to urban growth management. Today, with state participation in the construction, implementation, and enforcement of all UGBs, intergovernmental participation remains the characteristic feature of the growth-boundary approach to urban growth management.

Following the model pioneered in Salem, the architects of the statewide land use program included UGBs as a central feature of the land use system. Goal 14 of the statewide goals and guidelines states: "To provide for the orderly and efficient transition from rural to urban land use ... Urban Growth Boundaries shall be established to identify and separate urbanizableable land from rural land" (Oregon LCDC, 1976). Among the many purposes of UGBs are the preservation of farmland beyond urban development, the efficient allocation of facilities to accommodate growth, reduction in air, water, and land pollution through greater control over the location and intensity of development, and the creation of a distinctly urban ambience (Einsweiler, et. al., 1976). Local comprehensive plans must contain sufficient urban land within UGBs to meet the requirements for housing, industry and commerce, recreation, open space, and all other urban uses until the year 2000; all land outside UGBs is subsequently preserved for rural use until after the year 2000 .

The UGB represents a hierarchical, intergovernmen- 
tal approach to urban growth management. For their part, local governments may employ tax incentives and disincentives, fee and less than fee acquisition of land, zoning, and urban service programming to guide urban development within UGBs. The LCDC will not, however, allow urban development outside approved UGBs. To ensure local compliance with statewide UGB policies, the LCDC can withhold state revenues and building permits from recalcitrant local governments. Thus, UGBs are enforced jointly by state and local governments, while the enforcement of land use controls within UGBs remains primarily the responsibility of local governments. This hierarchy of enforcement standardizes statewide the restrictions embodied in UGBs, while allowing variability in the restrictions imposed by local land use controls.

The primary intention of UGBs in Oregon's statewide land use program is to manage urban growth without major disruptions of the land and housing market. Whereas growth management in other jurisdictions has taken the form of density constraints, development moratoria, and population caps (Scott, et al., 1975), the intent of UGB policy in Oregon is not to limit growth, but simply to manage its location. By restricting urban development to a well defined, contiguous area, the size of which is based on the best available information about development trends, it was thought that growth could be accommodated without permitting urban sprawl and without raising the cost of housing and other urban activities, at least in the short term (Metropolitan Service District, 1979; Beaton, et al., 1977). But the construction of UGBs raised troublesome conceptual issues concerning the development process (Knaap, 1982, 1985; Nelson, 1985, 1986).

Under the requirements of Goal 14, local governments must plan, a priori, where and when urban development will take place. Such planning is difficult and controversial. Too little urban land could cause land price inflation; too much would not prevent urban sprawl. This difficulty led the Metropolitan Service District (Metro), the Portland metropolitan land use authority, to include 15.3 percent more land inside the Portland area UGB than was necessary to accommodate projected urban growth by the year 2000 (Metro, 1979). This "market factor" adjustment was reduced from 25 percent at the insistence of the LCDC. Apparently, the LCDC insists that there should be very little undeveloped land within UGBs by the year 2000 as undeveloped urban land existing in that year implies that too much land was removed from the rural and agricultural land base. Thus, in addition to a lower market factor, Metro also established an intermediate growth boundary (IGB) to prevent urbanization of prime agricultural land between the IGB and UGB for at least 10 years.

Construction and implementation of UGBs in other urban areas proved to be a protracted political process. Turf battles often arose between city and county governments and, in the larger metropolitan areas, between city governments. Most common, however, have been conflicts between local governments and the DLCD. As did Portland, other city governments frequently sought to include more land inside UGBs than DLCD felt was justified by demographic and economic trends (Rohse, 1983). DLCD was not as compromising, though, with jurisdictions less powerful politically than Metro. In most other cases DLCD forced local governments to eliminate or reduce to virtually nothing the market factor adjustment to UGBs. In fact, only the Salem UGB, which predates the existence of LCDC, is allowed a significant market factor adjustment.

Although it is difficult to generalize the relationship between local governments and the state, the long track record of state approval and local implementation suggests that state and local land use objectives differ significantly. State-level review of local plans led to much compromise in the content of local land use plans. We conjecture, however, that state participation in the land use program has resulted in less land being available for urban development than would have been under a purely local system of land use regulation. More importantly, we hypothesize that state participation in the enforcement of UGBs, rather than the enforcement of other land use instruments, has enhanced the effects of these instruments on land markets and land allocation. In what follows, we examine studies that have measured the effects of land use controls in Oregon for consistency with our hypothesis. Following this examination we consider the implications and future role of the urban growth boundary in the Oregon land use system.

\section{Theoretical Analysis}

Analyses of the effects of UGBs followed shortly after their implementation in Portland and Salem. Although UGBs are multi-objective instruments, most research on the effects of UGBs has focused on land values. This occurred primarily for two reasons. First, most of the early analyses of UGBs were conducted by economists. According to conventional economic theory, land use instruments that in any way influence land use or land allocation must affect land values. Thus, by economic reasoning, a test for impacts on land values by UGBs is in effect a test for impacts on land use and allocation. The second reason for the research focus on land values was the widespread concern that the land use program in general, and UGBs in particular, contributed to, if they did not cause, the rapid escalation of land and housing costs in Oregon during the late 1970s. Although UGBs were 
intended to constrain urban growth, they were not intended to raise housing costs (Leonard, 1983). Thus, studies that demonstrated that UGBs did influence land use, through their influence on land values, raised concerns about their effects on housing costs.

The first theoretical analysis of the effects of UGBs on land values was published by Whitelaw (1980). Viewing UGBs as potential constraints on urban land supplies, Whitelaw argued that UGBs, if effective, would cause a gap at the UGB in the otherwise continuously downwardsloping bid-rent gradient for urban land. Holding other things constant, land values would be higher inside UGBs than land values outside UGBs. This effect occurs when those who would have bid for land outside UGBs are constrained to bid for land inside UGBs. As demand for urban land is shifted away from locations outside the UGB, urban land values rise and rural land values fall. In Whitelaw's view, UGBs operate much like ordinary zoning constraints, increasing urban land values by reducing the supply of urban land below market prescribed levels.

In Figure $1, R m$ represents the bid-rent gradient for urban land in the absence of an UGB; $R g$ represents the bidrent gradient for urban land after the imposition of an UGB at $u(2)$. Following the imposition of an UGB, land values at distances greater than $u(2)$ fall as urban development is no longer allowed. Land values at distances less than $u(2)$ rise, as those who would have bid for land outside the UGB are constrained to bid for land inside the UGB. Higher land values in turn increase urban densities as capital is substituted for more costly land. (See Mills and Hamilton [1984] for a discussion of the effects of land prices on urban densities.) The gap in the gradient, $R \boldsymbol{g}$, offers a measure of the effects of the UGB: the greater the gap, the greater the impact.

Knaap $(1982,1985)$ extended Whitelaw's theory. Knaap observed that UGBs are imposed on an existing patchwork of zoning regulations. Therefore, because land on both sides of UGBs is zoned, the supply of urban land is currently constrained by zoning, not UGBs. UGBs, according to $\mathrm{Knaap}$, affect land values by specifying when existing zoning restrictions can be changed. Land zoned for rural use outside UGBs will remain so until at least the year 2000; land zoned for rural use inside the UGB may not. Thus, UGBs affect land values only by influencing the expected date of up-zoning.

In Figure 2, $R(u)$ and $R(r)$ represent the bid-rent gradients for urban and rural land, respectively, where the allowed use and, thus, bid-rent is determined by zoning. Urban land values are influenced by a number of factors (e.g., distance to the urban core, amenity levels, urban services, etc.) but not by UGBs. Because UGBs do not influence the future zoning of urban land, urban land values would be equal on both sides of an UGB. Land values in rural zones are, however, influenced by UGBs. This occurs because rural land inside UGBs may, through zoning changes, become urban land before the year 2000 ,

Figure 1

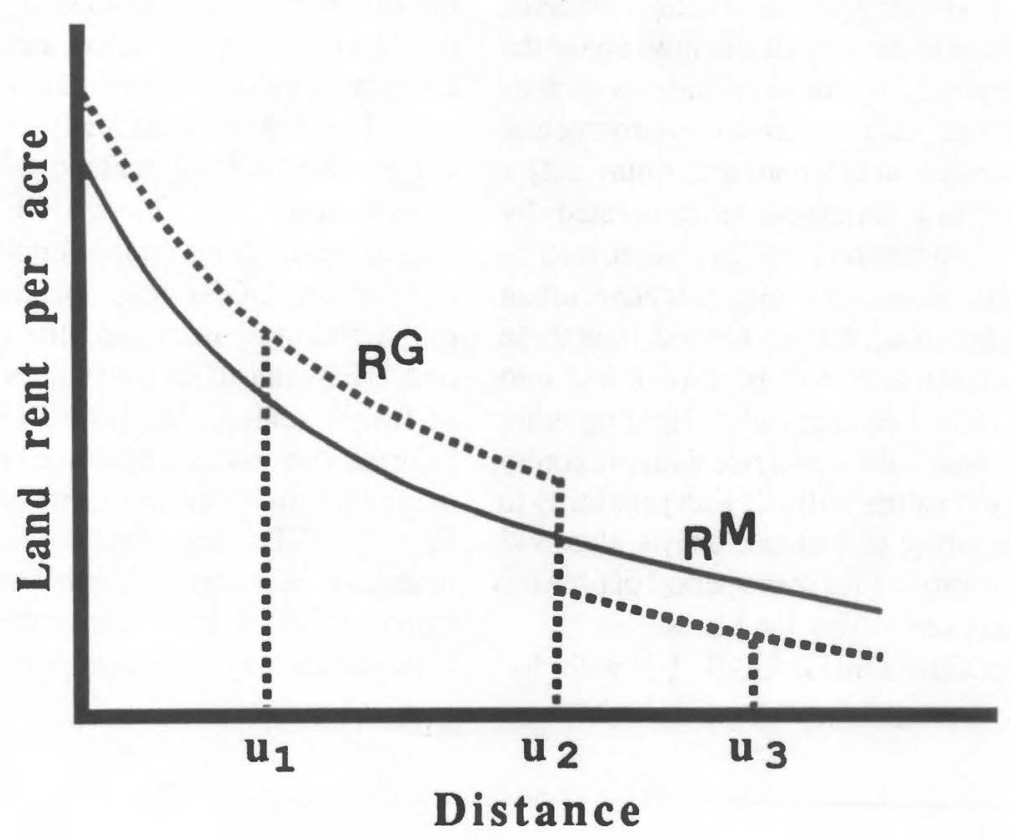


Figure 2

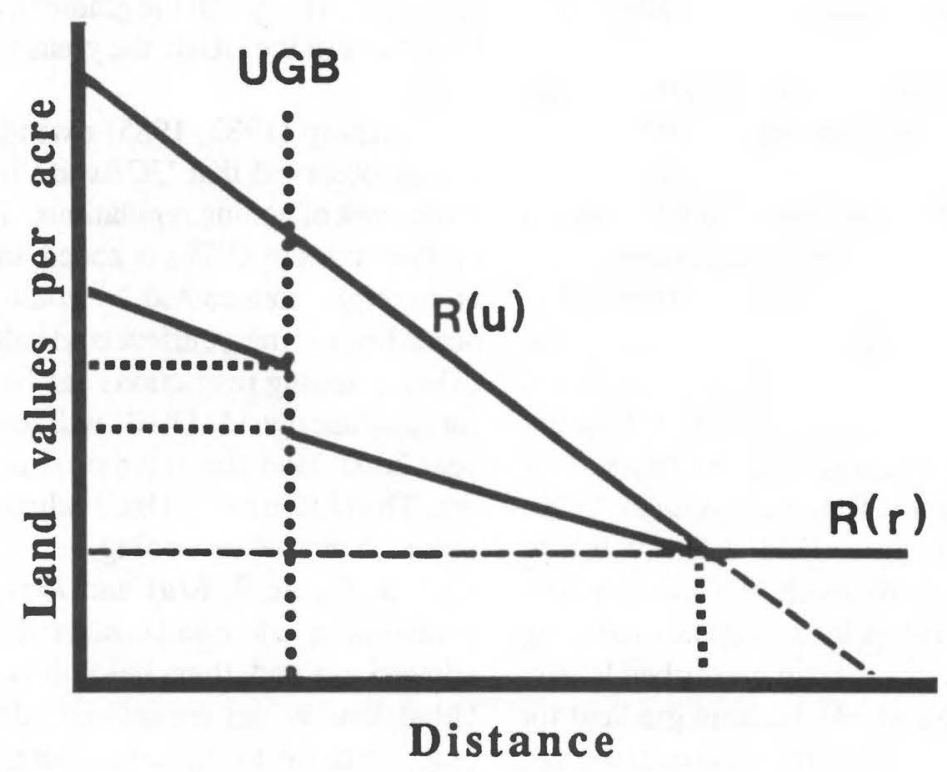

while rural land outside UGBs may not. Therefore, rural land values may be higher inside UGBs due to expectations of earlier conversion to urban land, and, according to Knaap, UGBs affect land values only in rural zones via expectations concerning the timing of zoning changes. Nelson $(1985,1986)$ extended Knaap's analysis by focusing on spillover effects between urban and rural land uses.

Nelson, viewing conservancy zoning that is applied to land outside UGBs as creating privately held greenbelts, suggested that urban residents near UGBs may enjoy the quasi-public goods produced by those greenbelts such as rural scenery, open space, and improved environmental quality. Similarly, farmers near urban areas may suffer from production-inhibiting externalities generated by urban residents such as congestion costs, pollution, restrictions on the use of chemicals, and other negative urban spillovers (disamenities). If so, Nelson argued, then these location-specific characteristics will be capitalized into urban and rural land values, respectively. Holding other things constant, urban land values will rise with proximity to UGBs while rural land values will fall with proximity to the UGB. Thus, according to Nelson, UGBs also will affect land values by specifying for some period of time the boundary between non-conforming land uses.

In Figure 3, land values inside UGBs fall with distance from the urban core until distance $u(1)$; beyond distance $u(1)$, land values increase with distance as the value of proximity to the UGB more than offsets the decline of value with distance from the urban core. This occurs because the urban land market will internalize the quasi-public goods that are produced by greenbelts located just beyond the UGB. As urban development imposes production-inhibiting externalities on nearby greenbelt land, land values outside UGBs increase with distance from the urban core until $u(3)$; beyond $u(3)$ the decline in value due to distance from the urban core more than offsets the increase in value due to distance away from the UGB.

These theoretical analyses of the effects of UGBs suggest that UGBs affect land values and land allocation in one of three ways. First, UGBs can affect land values through restrictions on the supply of urbanizable land. In this respect UGBs may increase the density of urban development by increasing the price of urban land. Second, UGBs can affect land values through the specification of future zoning changes. In this respect UGBs alter expectations concerning future land use regulations, which may, in turn, may alter current investment decisions. Finally, UGBs can affect land values by specifying the boundary between non-conforming land uses. In this respect UGBs define the location of future urban development which may alter current location decisions. 
Figure 3

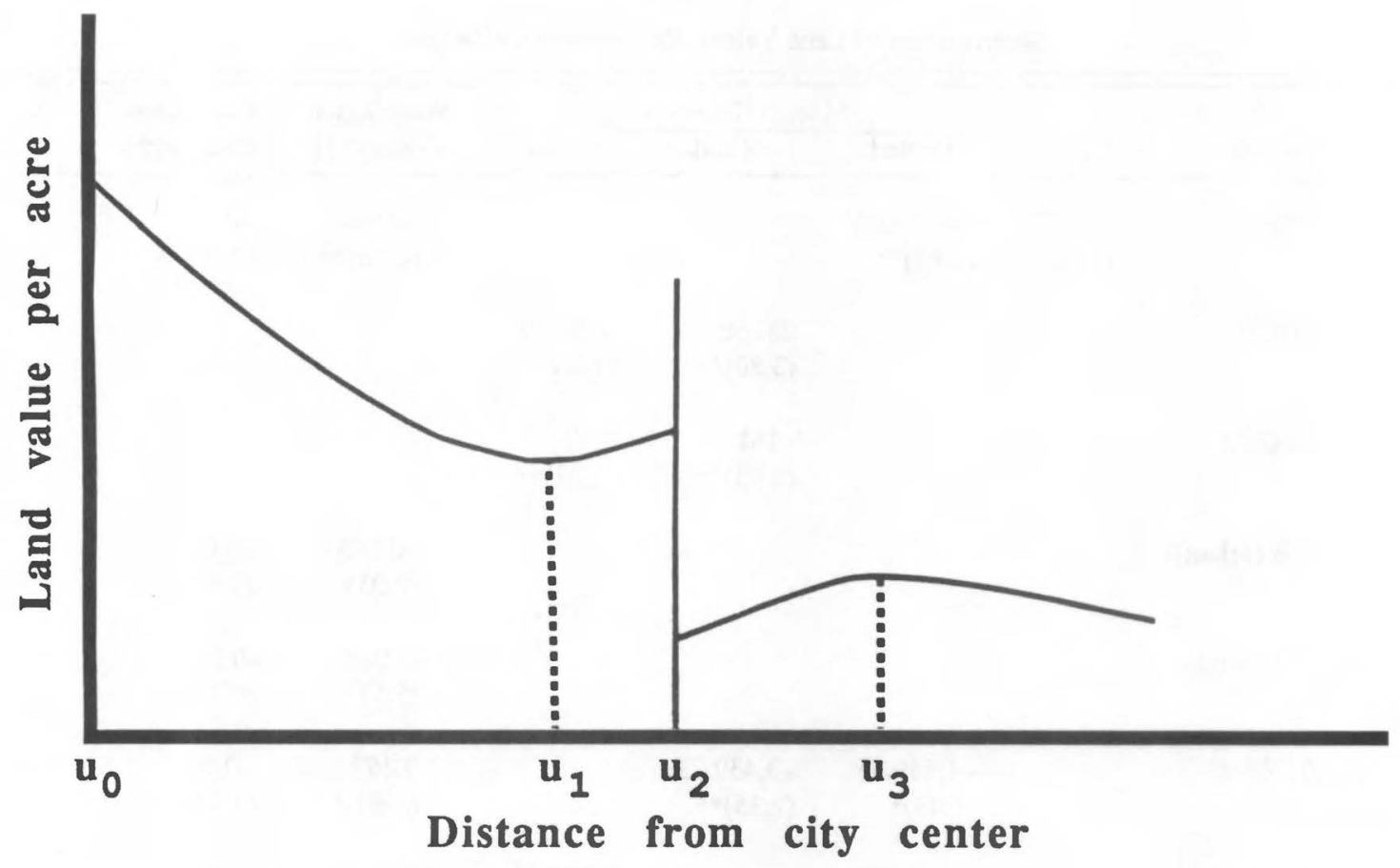

Empirical Evidence

The empirical evidence concerning the effects of UGBs on land values is now sizable. Without exception, researchers have used the hedonic price approach to estimate the contribution to value of various land attributes (Griliches, 1971; Rosen, 1974). The hedonic price equation can be expressed as follows:

$$
P=b(0)+b(1) X(1)+b(2) X(2)+b(3) U G B+e,
$$

where

$$
\begin{aligned}
& P \quad=\text { price per acre of land, } \\
& X(1)=\text { extraneous land attributes, } \\
& X(2)=\text { local land use constraints, } \\
& \text { UGB }=\text { location relative to the UGB ( } 1 \text { = outside), } \\
& \quad \text { and } \\
& \text { e } \quad=\text { a random error. }
\end{aligned}
$$

In the above equation, the $b(i)$ capture the contributions to value of various land attributes. For example, $b(3)$ captures the price effects of UGBs; if $b(3)$ is significant and negative, then land values are lower outside UGBs than inside UGBs. The empirical results reported by Beaton, et al. (1976), Knaap (1985), and Nelson (1986) are presented in Table 1.
The first empirical analysis of the effects of an UGB was conducted by Beaton, et al. (1976) for the Salem Area Council of Governments, just two years after the Salemarea UGB was drawn. Beaton, et al. gathered a sample of 105 sales of unimproved land in 1976 both inside and outside the UGB. Including four explanatory variables in addition to the UGB they were able to explain approximately 40 percent of the variation in land values in a linear hedonic model, but they could not attribute any of the variation to the UGB. In other words, they did not find the value of land influenced by location with respect to the UGB. From this they concluded that the UGB had not been in place long enough to have influenced land values. That is, the UGB was either too new to have influenced the expectations of participants in the Salem-area land market, or the UGB had been drawn with sufficient developable land to meet the demand over the foreseeable future.

The nextempirical analysis of the effects of UGBs on land values was conducted by Knaap $(1982,1985)$. Knaap gathered a sample of over 400 sales of unimproved land during the fiscal year 1979-1980 from the Portland metropolitan area. Knaap included 10 explanatory variables, in addition to the UGB, and was able to explain nearly 75 percent of the variation in land values in a non-linear (double log) hedonic model. Knaap also included a variable to capture the effects on land values of the intermediate growth boundary, the result of the political compromise 
Table 1

Determinants of Lane Values, Regression Coefficients

\begin{tabular}{|c|c|c|c|c|c|c|}
\hline \multirow[b]{2}{*}{ Variable } & \multirow[b]{2}{*}{ Salem $\dagger$} & \multicolumn{3}{|c|}{ Marion Countyt† } & \multirow{2}{*}{$\begin{array}{l}\text { Washington } \\
\text { Countyt+† }\end{array}$} & \multirow{2}{*}{$\begin{array}{l}\text { Clackamas } \\
\text { County }+t \dagger\end{array}$} \\
\hline & & Pooled & Rural & Urban & & \\
\hline UGB & $\begin{array}{l}-11.57 \\
(0.02)\end{array}$ & $\begin{array}{l}-3,877.88 \\
(2.81)^{* *}\end{array}$ & & & $\begin{array}{l}-0.980 \\
(4.10)^{* *}\end{array}$ & $\begin{array}{l}-0.645 \\
(2.50)^{* * *}\end{array}$ \\
\hline DUGB & & & $\begin{array}{l}280.95 \\
(3.80)^{* *}\end{array}$ & $\begin{array}{l}-150.29 \\
(1.30)\end{array}$ & & \\
\hline DUGB2 & & & $\begin{array}{l}-161 \\
(2.93)^{* *}\end{array}$ & $\begin{array}{l}2.97 \\
(2.32)^{* *}\end{array}$ & & \\
\hline IGB (urban) & & & & & $\begin{array}{l}-0.055 \\
(0.03)\end{array}$ & $\begin{array}{l}-0.064 \\
(0.28)\end{array}$ \\
\hline IGB (rural) & & & & & $\begin{array}{c}-0.944 \\
(5.57)^{* *}\end{array}$ & $\begin{array}{r}-0.258 \\
(0.78)\end{array}$ \\
\hline ZONING & & $\begin{array}{l}-1,649.35 \\
(1.46)^{*}\end{array}$ & $\begin{array}{l}-3,439.73 \\
(2.35)^{* * *}\end{array}$ & & $\begin{array}{l}0.267 \\
(1.80)^{*}\end{array}$ & $\begin{array}{l}-0.407 \\
(1.74)\end{array}$ \\
\hline SERVICE & $\begin{array}{l}-2,673 \\
(3.95)^{* *}\end{array}$ & $\begin{array}{l}1,964.91 \\
(1.70)^{*}\end{array}$ & & $\begin{array}{l}2,900.40 \\
(0.96)\end{array}$ & $\begin{array}{l}0.148 \\
(1.71)^{*}\end{array}$ & $\begin{array}{l}0.470 \\
(2.79)^{* *}\end{array}$ \\
\hline TAX & & $\begin{array}{l}-1,141.40 \$ \\
(1.17)\end{array}$ & $\begin{array}{l}-559.268 \\
(0.41)\end{array}$ & $\begin{array}{l}4,727.72 \S \\
(1.11)\end{array}$ & $\begin{array}{l}0.414 \\
(0.95)\end{array}$ & $\begin{array}{l}-1.442 \\
(3.35)^{* * *}\end{array}$ \\
\hline SIZE & $\begin{array}{l}-2,690 \\
(6.11)^{* *}\end{array}$ & $\begin{array}{l}-126.43 \\
(3.60)^{* *}\end{array}$ & $\begin{array}{l}-34.78 \\
(0.53)\end{array}$ & $\begin{array}{l}56.51 \\
(0.72)\end{array}$ & $\begin{array}{l}-0.186 \\
(2.85)^{* *}\end{array}$ & $\begin{array}{l}-0.665 \\
(10.12)^{* *}\end{array}$ \\
\hline DISTANCE & $\begin{array}{l}-17.9 \\
(0.17)\end{array}$ & $\begin{array}{l}0.52 \\
(0.09)\end{array}$ & $\begin{array}{l}-33.32 \\
(2.75)^{* * *}\end{array}$ & $\begin{array}{c}-57.49 \\
(1.78)^{*}\end{array}$ & $\begin{array}{l}-0.404 \\
(2.36)^{* *}\end{array}$ & $\begin{array}{l}-0.019 \\
(0.12)\end{array}$ \\
\hline INCOME & & $\begin{array}{l}1.48 \\
(0.11)\end{array}$ & $\begin{array}{l}0.61 \\
(0.03)\end{array}$ & $\begin{array}{l}-25.47 \\
(0.42)\end{array}$ & $\begin{array}{l}1.055 \\
(2.31)^{* *}\end{array}$ & $\begin{array}{l}0.311 \\
(1.11)\end{array}$ \\
\hline DATE & & $\begin{array}{l}168.30 \\
(4.00)^{\text {** }}\end{array}$ & $\begin{array}{l}58.36 \\
(0.77)\end{array}$ & $\begin{array}{l}301.71 \\
(3.05)^{* *}\end{array}$ & $\begin{array}{l}0.085 \\
(1.73)^{*}\end{array}$ & $\begin{array}{l}0.057 \\
(1.16)\end{array}$ \\
\hline SCHOOL & $\begin{array}{l}-1,323 \\
(2.73)^{* *}\end{array}$ & & & & & \\
\hline PRODUCT & & $\begin{array}{l}240.02 \\
(2.07)^{* *}\end{array}$ & $\begin{array}{l}907.13 \\
(3.25)^{* *}\end{array}$ & $\begin{array}{l}48.49 \\
(0.11)\end{array}$ & & \\
\hline PLAT & & & & & $\begin{array}{l}0.506 \\
(4.23)^{* *}\end{array}$ & $\begin{array}{l}0.084 \\
(0.44)\end{array}$ \\
\hline NOCITY & & & & & $\begin{array}{l}-0.374 \\
(3.61)^{* * *}\end{array}$ & $\begin{array}{l}-0.140 \\
(1.11)\end{array}$ \\
\hline RACE & & & & & $\begin{array}{l}-1.048 \\
(0.39)\end{array}$ & $\begin{array}{l}6.278 \\
(1.34)\end{array}$ \\
\hline
\end{tabular}


PORTLAND

CONSTANT

R2

$\mathrm{N}$
$8,531.4 \quad 1,214.10$

0.38

105
0.33

209
0.255

$11.061 \quad-5.751$

0.81

188

where: UGB = location with respect to the urban growth boundary $(1=$ outside);

DUGB = distance from the UGB in feet;

DUBG $^{2}=$ distance from the UGB in feet squared;

IGB (urban) = location with respect to the intermediate growth boundary ( 1 = outside, urban parcels only);

IGB (rural) = location with respect to the intermediate growth boundary ( 1 = outside, rural parcels only);

ZONING = local land use designation ( $1=$ urban use, $0=$ rural use);

SERVICE = location with respect to urban service ( 1 = within 300 feet of sewer lines);

TAX = tax rate per $\$ 1,000$ of assessed value;

SIZE = parcel size in acres;

DISTANCE = distance from the urban core in minutes of travel time;

INCOME = median family income of census tract;

DATE = monthly index of date of sale $(0=$ beginning month);

SCHOOL = location with respect to urban school district $(1=$ inside);

PRODUCT = pasture productivity in half-ton units;

TERMS = seller participation in sale ( 1 = participation);

PLAT = location with respect to platted subdivision (1 = within);

NOCITY = location with respect to incorporated municipality ( 1 = within);

RACE = percent of census population that is white;

PORTLAND = location with respect to Portland City limits ( $1=$ within $)$.

Note: Numbers in parentheses are corresponding $t$ Statistics.

†Source: Beaton, et. al., 1977

†tSource: Nelson, 1986

t†'Source: Knaap, 1985

* Significant at 0.10 level; one-tail test

**Significant at 0.05 level; one-tail test

8Signifies participation in Farm Tax Deferral Program

between Metro and the DLCD.

Knaap found the effects of the UGB significant in both Washington and Clackamas counties. Further, Knaap found the effects of the intermediate growth boundary (the IGB, a short-term UGB) influential in Washington County on land values in rural zones, but not in urban zones. This finding was consistent with the theory that UGBs (and IGBs) specify the timing of zoning changes, not the supply of urban land. Knaap also found the influence of locally enforced land use constraints (e.g., zoning, taxes, sewer services, etc.) different between counties. This Knaap attributed to differences in enforcement practices between local governments.

The latest study of the effects of UGBs was published by Nelson $(1985,1986)$. Nelson gathered a sample of 209 sales of unimproved land from 1977 to 1979 within and three miles beyond the Marion County portion of the Salem area UGB. Nelson included 10 variables, in addition to the UGB, and was able to explain 58 percent of the variation in land values in a linear hedonic model. Nelson found the effects of the UGB significant on land values in Marion County only two years after the study by Beaton, et al. Not only did Nelson find land values lower outside than inside the UGB, he also found the effects of the UGB varied by location. The combined effects of the variables DUGB and DUGB2, representing distance from the UGB and distance from the UGB squared, imply that urban land values rise with distance from 5,000 feet inside the UGB toward the UGB and that rural land values fall with distance from 17,000 feet outside the UGB toward the UGB. The empirical results strongly suggest that UGBs have had significant effects on land values consistent with economic theory.

\section{Implications}

As the central feature of the Oregon land use program, UGBs have received considerable analysis. Re- 
searchers, primarily economists and planners, have offered theoretical models and empirical tests of those models. Although the tests have been performed in only two metropolitan areas, the consistency of the results tends to substantiate the models. In short, the results imply that UGBs take little time to affect land markets (probably no more than two years based on reported analyses). The effects are manifest through expectations about future zoning changes, and the effects vary by distance from UGBs. UGBs have thus proven effective land use instruments in shifting the demand for urban land to locations within UGBs, specifying the timing of future zoning changes, and generating both public and quasi-public goods benefiting urban land (but also generating disamenities affecting agricultural land just outside UGBs). All these effects were predictable and measurable.

While the effects of UGBs have been predicted and shown to be significant influences on regional land values in every examination of a state-approved UGB, the same cannot be said for the package of land use controls applied within UGBs by local governments. The land market effects of locally enforced land use controls vary markedly by jurisdiction. This variation in the effects of local land use instruments is consistent with the variation in enforcement these instruments receive. The evidence suggests that once the UGB is acknowledged by the DLCD, it begins to influence expectations and, thus, land values. The evidence also suggests that the enforcement and, therefore, the effects of local controls within UGBs vary by jurisdiction. Judging by the empirical results, urban development within the UGB in Salem is controlled by zoning, in Clackamas County by urban service provision, and in Washington County by the combination of zoning, intermediate growth boundaries, and urban service provision. Further, these results are consistent with the stated practices of these local governments (Metro, 1979).

UGBs are enforced strictly and ubiquitously throughout the state, and land values statewide are similarly affected as a result. When local governments guide urban development within UGBs with strictly enforced local controls, urban land values are affected by UGBs as well. But when local governments guide urban development within UGBs with weakly enforced local controls, only the UGB but not locally enforced controls affect land values significantly. Thus, state participation in the enforcement of UGBs around all urban areas of the state appears to have contributed to the significance and predictability of the effects of these instruments on urban land values.

The effects of the UGB on the efficiency of land markets, however, remains uncertain. The differences between local governments and DLCD revealed through the acknowledgement process (DeGrove, 1984; Leonard, 1983; Rohse, 1983) suggest that state involvement in the construction of UGBs has resulted in greater constraint on the development process than would have occurred otherwise. But because local governments retain control of the rate of urban development through utility extension policy, rezoning, and other techniques, whether less land has been developed as a result of UGBs remains an unanswered question. And whether UGBs will before the year 2000 unambiguously restrict local governments in making urban land available will not be known for some time.

What is known, as revealed by the impacts on land prices, is that UGBs have influenced the expectations of land market participants and, therefore, current land allocation. Individuals are willing to pay more for agricultural land inside than outside UGBs because of expectations of earlier urban development. Further, individuals are willing to pay more for urban land near UGBs and less for agricultural land near UGBs because of expectations concerning the future location of the urban/rural boundary. These findings have significant implications concerning efficiency and equity.

From an efficiency perspective, UGBs have provided information about future development that, if accurate, could improve the dynamic efficiency of the land market. For example, if it is known that urban development will soon take place on agricultural land inside the UGB, then improvements in agricultural production are unlikely unless they amortize before the year 2000. Similarly, improvements on agricultural land outside the UGB become more likely even if they do not amortize until after the year 2000. Further, those who wish to reside near the urban/rural border can identify, through the placement of the UGB, the parcels of land for which they must bid. And those who wish to farm away from the urban/rural border know the same. Thus, dynamic efficiency is enhanced as information about future development is capitalized into land values and market participants can react accordingly.

The effects on land values also have equity implications. With the imposition of an UGB, wealth is transferred to those who own land inside the UGB from those who own land outside the UGB. Wealth is also transferred to those who own urban land near the UGB from those who own urban land away from the UGB; and from those who own agricultural land near the UGB to those who own agricultural land away from the UGB. These are transfers of wealth that occur without explicit consideration of equity consequences.

To some, then, UGBs may cause capricious and unwarranted redistributions of wealth. Such redistribution, however, is similar to that which occurs as a result of traditional zoning (see, e.g., Fischel, 1985; Hagman and 
Juergensmeyer, 1986; Mills and Hamilton, 1984). But it certainly is not clear that the wealth redistribution that results from state-mandated UGBs is more or less equitable than what would result from traditional zoning without UGBs. Wealth transfers also occur in the absence of UGBs. But because of the required public input into the construction of UGBs (Oregon LCDC, 1976), wealth transfers attributable to UGB policies are less likely to accrue to those with disproportionate influence on local land use regulations (for contrasts, see Babcock, 1966). Further, because UGBs designate zoning changes far in advance, wealth transfers attributable to UGB policies are more explicit and accrue gradually over time.

\section{Toward the Future}

What remains unsettled, even at the state level, is the role UGBs will play in the future. Existing UGBs are programmed to expire in the year 2000 . What will happen after that is not clearly understood. Since, by design, most land within UGBs will become urbanized, urban development after the year 2000 must take place outside currently existing UGBs. The only questions that remain are where and when that development will be allowed to occur.

The research reviewed here suggests that the influence of UGBs on land markets depends on timing, credibility of enforcement, and location. Thus, the influence of the UGBs on the regional land market will dissipate if they are discontinued, not enforced, or moved. The information provided by UGBs will become lost or, even worse, inaccurate. Once again the location of future urban development will become uncertain, the value of all land within the region would include a speculative component, and new or maintenance investments in agricultural land will fall as owners of such land become less certain about amortizing those costs. The efficacy and short-term success of UGBs will have become lost.

Alternatively, if new UGBs were to be drawn around existing UGBs, or if rural land that would be marginally productive in agriculture were set aside for new urban development within commuting range of the existing UGBs, the effectiveness of the UGB policies would not be lost and no serious disruptions in the regional land market need occur. If the restrictions of the existing UGBs remained in force until expiration, land within existing UGBs would be developed as planned, and land outside existing UGBs would remain undeveloped until after the year 2000 . After the year 2000 development could take place outside the existing UGBs, but only inside the new UGBs at least until the expiration date of the new UGBs. Constructing new UGBs without removing old UGB would allow UGB policies to continue to have meaning up to and well after the year 2000.

Preserving the credibility of UGB policies even as the expiration date approaches, in the manner we have outlined, provides important benefits. First, planners could design new comprehensive land use plans for land inside new UGBs (whether they were extensions of existing UGBs or UGBs around envisioned new communities in the marginally productive countryside). In fact, such planning could be done with far more wisdom than the planning undertaken for the existing and pioneering UGBs. Second, participants in the regional land market can continue to make long-term development decisions consistent with both pre- and post-2000 land use policy. Those who wish to use land now or in the future for urban uses would be restricted to areas within existing, expanded, or new UGBs. Those who wish to use land now or in the future for non-urban uses would be restricted, by price, to areas outside UGBs. This is perhaps the greatest potential contribution of UGBs and comprehensive planning in general. Third, preserving the restrictions of the original UGBs, and extending those restrictions to expanded or new UGBs, would maintain the credibility of UGB policies as meaningful instruments. This credibility has been earned for the moment, as the analyses reviewed here show, in part as a result of state participation in land use regulation. Whether this credibility will survive to the year 2000 and beyond depends on whether the State begins now to address the issues we have raised.

\section{References}

Babcock, R. The Zoning Game: Municipal Practices and Policies. Madison, Wisc.: University of Wisconsin Press, 1966.

Beaton, C. R., J. S. Hanson, and T. H. Hibbard. "The Salem Area Urban Growth Boundary: Evaluation of Policy Impacts and Recommendations for the Future." Salem. Oregon: Mid-Willamette Valley Council of Govemments, 1976.

Bosselman, F. and D. Callies. The Quiet Revolution in Land Use Control, Prepared for the U.S. Council on Environmental Quality. Washington, D.C.: U.S. Printing Office, 1971.

DeGrove, J. M. Land Growth and Politics. Chicago, Illinois: Planners Press, American Planning Association, 1984.

Einsweiler, Robert C., Michael Gleeson, Ian Traquair Ball, Alan Morris, and Diane Sprague. Urban Growth Management Systems. Planning Advisory Service Report Nos. 309, 310. Chicago, Illinois: American Planning Association, 1976.

Fischel, William A. The Economics of Zoning Laws: A Property Rights Approach to American Land Use Controls. Baltimore, Maryland: Johns Hopkins University Press, 1985. 
Griliches, Z. Price Indexes and Quality Change. Cambridge, Massachusetts: Harvard University Press, 1971.

Hagman, Donald C. and Julian Juergensmeyer. Urban Planning and Land Development Control Law. St. Paul, Minnesota: West Publishing Co., 1986.

Healy, R. and J. Rosenberg. Land Use and the States. Baltimore, Maryland: Johns Hopkins University Press, 1979.

Knaap, G.J. The Price Effects of an Urban Growth Boundary: A Test for the Effects of Timing. Unpublished dissertation. Eugene, Oregon: University of Oregon, 1982.

"The Price Effects of Urban Growth Boundaries in Metropolitan Portland Oregon." Land Economics. 61:1 (1985). 26-35.

Leonard, J. H. Managing Oregon's Growth. Washington D.C.: The Conservation Foundation, 1983.

Metropolitan Service District. Urban Growth Boundary Findings. Portland, Oregon: 1979.

Mills, E. S. and B. Hamilton. Urban Economics. Glenview, Illinois: Scott Foresman, 1984.

Nelson, A. C. "Demand, Segmentation, and Timing Effects of an Urban Containment Program on Urban Fringe Land Values." Urban Studies. 22:3 (1985). 439-443.
. "Using Land Markets to Evaluate Urban Containment Programs." Journal of the American Planning Association. 52:2 (1986). 156-171.

Oregon Land Conservation and Development Commission. Statewide Goals and Guidelines. Salem, Oregon: 1976.

Pelham, T. G. State Land Use Planning and Regulation. Lexington, Massachusetts: Lexington Books, 1979.

Rohse, Mitch. Personal correspondence with Gerrit Knaap. 1983.

Rosen, S. "Hedonic Prices and Implicit Markets: Product Differentiation in Pure Competition." Journal of Political Economy. (January/February 1974). 34-55.

Rosenbaum, N. Land Use and the Legislature: The Politics of State Innovation. Washington, D.C.: The Urban Land Institute, 1976.

Scott, R. A., ed. Management and Control of Growth. Washington, D.C.: The Urban Land Institute, 1975.

Whitelaw, W. E. "Measuring the Effects of Public Policies on the Price of Urban Land." Urban Land Markets: Price Indexes, Supply Measures, and Public Policy Effects. J. T. Black and J. E. Hoben, eds. Research Report \#30. Washington, D.C.: The Urban Land Institute, 1980. 